\title{
WestVirginiaUniversity
}

THE RESEARCH REPOSITORY @ WVU

Graduate Theses, Dissertations, and Problem Reports

2005

\section{Factors that influence 4-H club membership retention in West Virginia}

David C. Hartley

West Virginia University

Follow this and additional works at: https://researchrepository.wvu.edu/etd

\section{Recommended Citation}

Hartley, David C., "Factors that influence 4-H club membership retention in West Virginia" (2005). Graduate Theses, Dissertations, and Problem Reports. 2199.

https://researchrepository.wvu.edu/etd/2199

This Thesis is protected by copyright and/or related rights. It has been brought to you by the The Research Repository @ WVU with permission from the rights-holder(s). You are free to use this Thesis in any way that is permitted by the copyright and related rights legislation that applies to your use. For other uses you must obtain permission from the rights-holder(s) directly, unless additional rights are indicated by a Creative Commons license in the record and/ or on the work itself. This Thesis has been accepted for inclusion in WVU Graduate Theses, Dissertations, and Problem Reports collection by an authorized administrator of The Research Repository @ WVU. For more information, please contact researchrepository@mail.wvu.edu. 
Factors That Influence 4-H Club Membership Retention in West Virginia

David C. Hartley

\author{
Thesis submitted to the \\ Davis College of Agriculture, Forestry, and Consumer Sciences \\ at West Virginia University \\ in partial fulfillment of the requirements \\ for the degree of
}

\author{
Master of Science \\ in \\ Agricultural and Extension Education \\ Deborah A. Boone, Ph.D., Chair \\ Harry N. Boone, Jr., Ph.D. \\ Stacy A. Gartin, Ph.D. \\ Jean M. Woloshuk, Ed.D.
}

Division of Resource Management

Morgantown, West Virginia
2005

Keywords: 4-H program, retention, enrollment, 4-H club membership, retention membership, agricultural education, and membership dropout 


\begin{abstract}
Factors That Influence 4-H Club Membership Retention in West Virginia David Christopher Hartley
\end{abstract}

The purpose of the study was to determine retention rates among youth enrolled in West Virginia's 4-H youth programs and to identify characteristics or trends associated with 4-H club member retention. The population of the study consisted of youth enrolled in 4-H clubs during the years 2002, 2003, and 2004. Membership records were selfreported by West Virginia County Extension Offices. This study used an ex post facto research design and the variables explored closely were: county, age, gender, grade in school, years in $4-\mathrm{H}$, and projects attempted. Findings for this study were that $30 \%$ of members were retained for the two-year cycle of which $40 \%$ were males and $60 \%$ females. Members retained for the two-year cycle had a mean age of 12.05 and a mean number of years membership of 3.56 which was higher than the mean of individuals that dropped out of the program. 


\section{ACKNOWLEDGEMENTS}

I would like to acknowledge and thank my graduate committee for their enormous help, talent, creativity, wisdom and dedication both in the classroom and through their service on my committee. Deborah A. Boone, Ph.D., Harry N. Boone, Jr. Ph.D., Stacy A. Gartin, Ph.D., and Jean M. Woloshuk, Ed.D, each have brought great insight and teamwork to this research process. I am very grateful for all they have given!

I could not have completed this thesis without the tremendous support from parents and family. Their love and belief in me have helped me pass through trying times. Thank you, for everything you have done for me in my life. 


\section{TABLE OF CONTENTS}

TITLE PAGE.

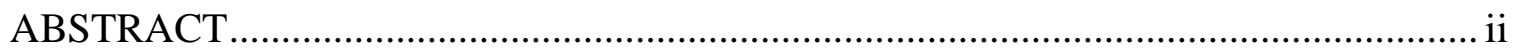

ACKNOWLEDGEMENTS ................................................................................ ii

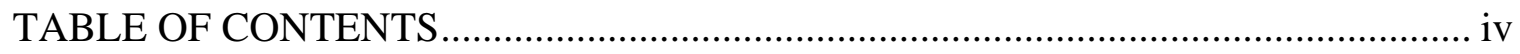

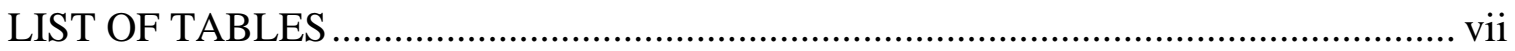

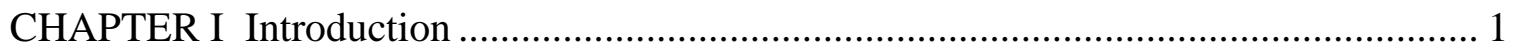

Problem Statement ...........................................................................................

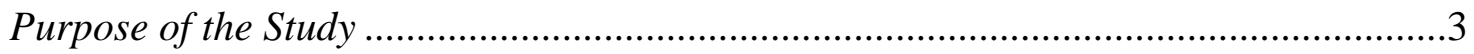

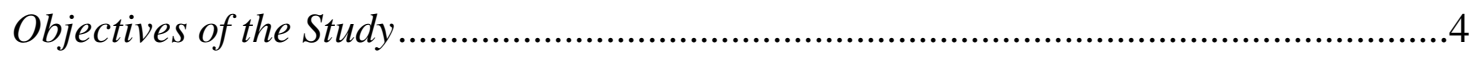

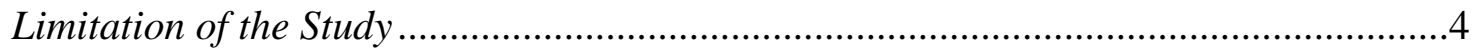

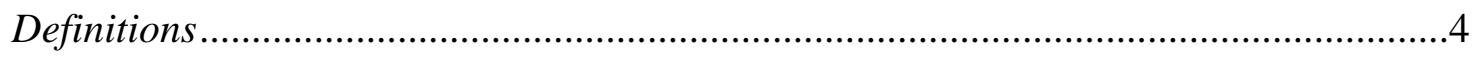

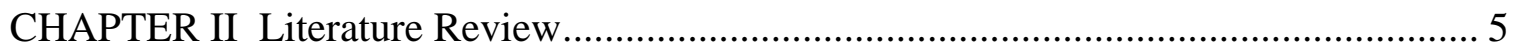

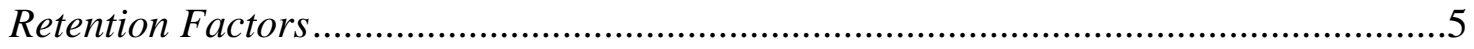

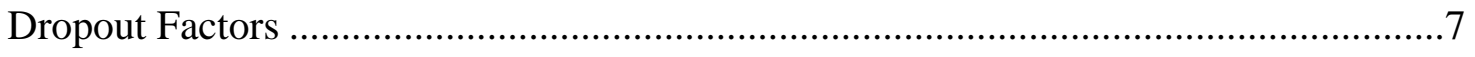

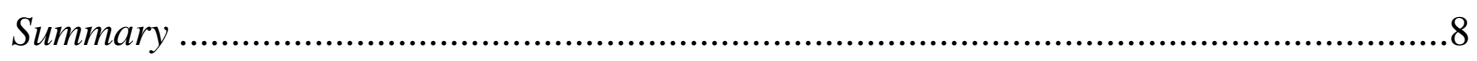

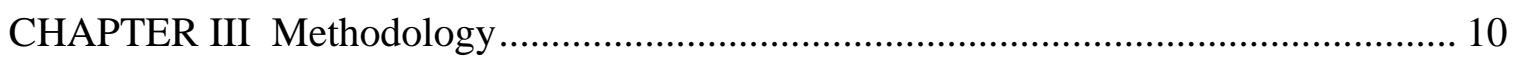

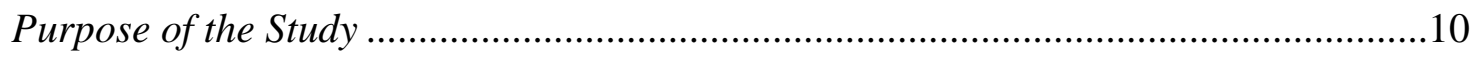

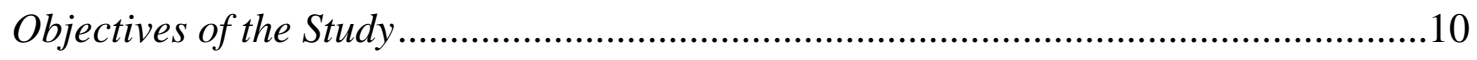

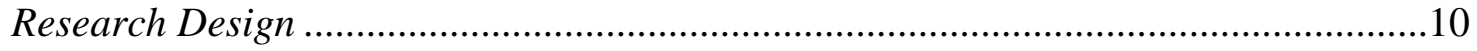

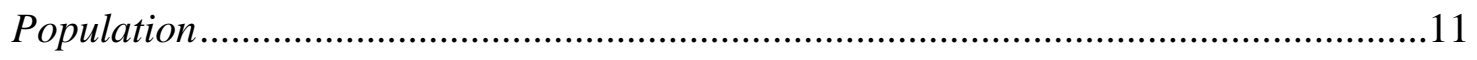

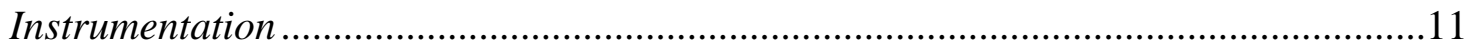


Data Collection Procedures ................................................................................11

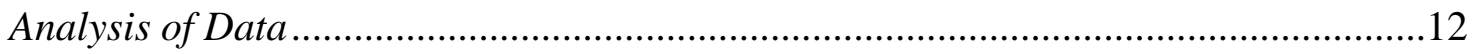

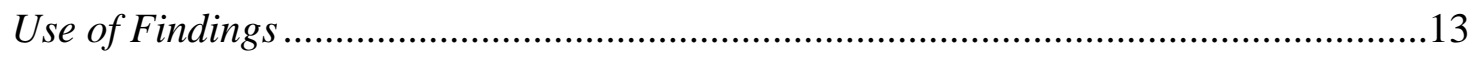

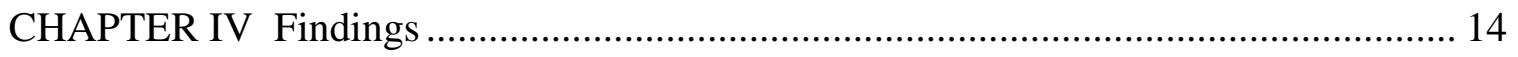

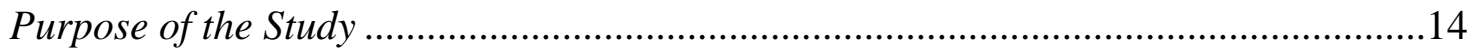

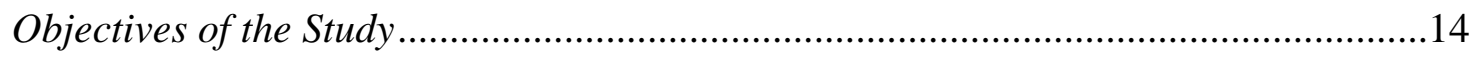

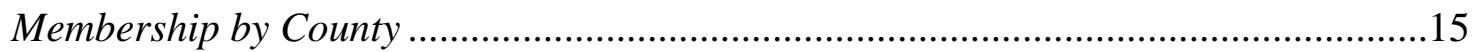

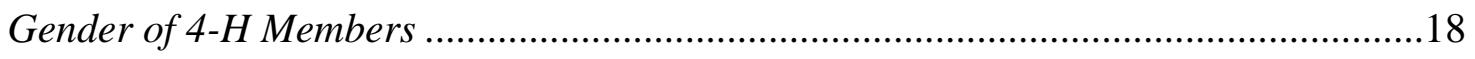

Grade in School, Age, and Years in 4-H............................................................18

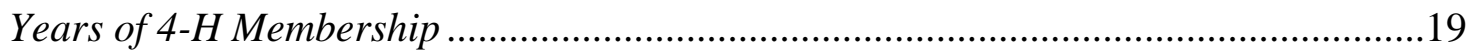

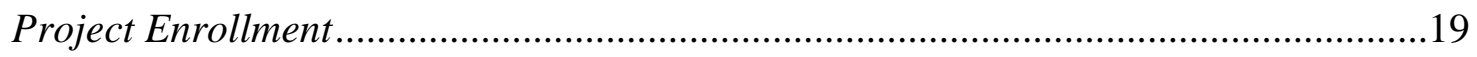

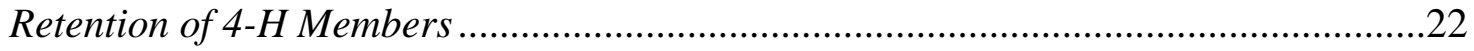

4-H Member Years of Membership, Age, and Grade Level, and Retention .................23

Gender of 4-H Members and Membership Retention .............................................29

Mean Age, Grade and Years of Membership of those Retained and Not Retained .......29

Number of Members Retained who Attempted at least one Project from a given Project

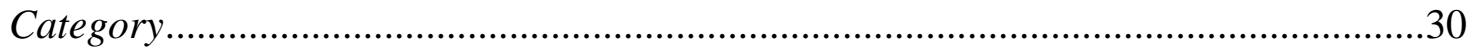

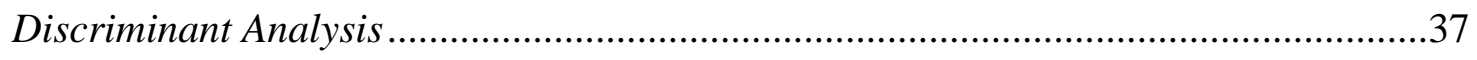

CHAPTER V Summary, Conclusions, and Recommendations.................................... 40

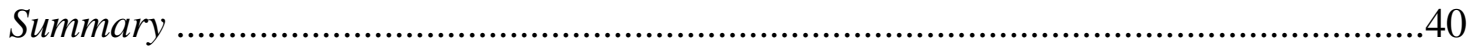

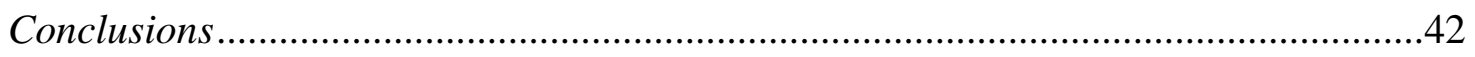

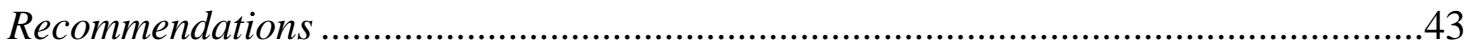

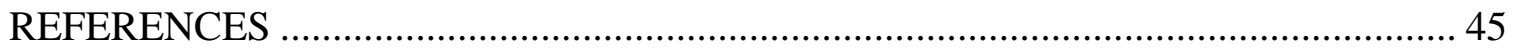


APPENDIX: 4-H Member Enrollment Card .............................................................. 48 


\section{LIST OF TABLES}

Table Title Page

$1 \quad$ 4-H Membership by County in West Virginia ............................................16

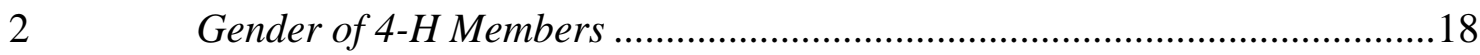

$3 \quad$ Grade, Age, and Years of 4-H Membership ............................................19

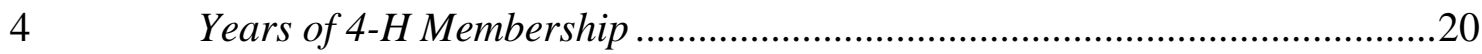

$5 \quad$ Number of 4-H Projects by Category and Year .........................................22

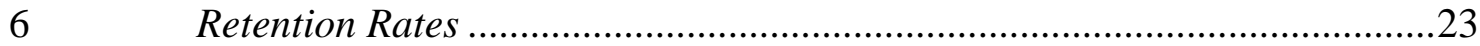

$7 \quad$ Comparison of Years of Membership and Retention ..................................25

8 Comparison of Age of 4-H Member and Retention .....................................26

$9 \quad$ Comparison of Grade Level of 4-H Member and Retention........................28

10 Comparison of Gender of 4-H Member and Retention...............................29

11 Mean Age, Grade and Years of Membership with Retention........................30

12 Number of Members Retained for 2002 to 2004 who Attempted at least one

Project from a given Project Category ....................................................32

13 Number of Members Retained and Not Retained for 2002 to 2003 who

Attempted at least one Project from a given Project Category .....................34

$14 \quad$ Number of Members Retained and Not Retained for 2003 to 2004 who

Attempted at least one Project from a given Project Category .....................36

15 Summary of the Discriminant Analysis for 2002 to 2004 ............................38

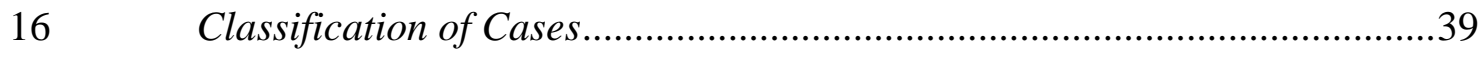




\section{CHAPTER I}

Introduction

The 4-H program is the largest government funded youth organization in the United States. This organization provides many opportunities for youth to develop, explore and expand abilities and knowledge through a four fold development program. In the year 1914, the United States Congress passed the Smith-Lever Act which created the Cooperative Extension Service within the United States Department of Agriculture. The Cooperative Extension Service allowed states to have county agents who brought information to local communities. The local leaders in counties organized agricultural clubs known as 4-H clubs which had a major requirement of completing a project and having club meetings. This was the start of the 4-H program in the United States $(4-\mathrm{H}$ History Timeline, n.d.).

As the program developed, the 4-H national headquarters set forth the 4- $\mathrm{H}$ mission that states, “4-H youth development education creates supportive environment for culturally diverse youth and adults to reach their fullest potential” (2000 Programs, n.d.). The ways that the 4-H mission are supported include: having community focused experience based learning that is both formal and non-formal, gaining skills that will enable youth throughout their lives, creating leadership and volunteerism opportunities for adults and youth, building youth and adult partnerships in programming and funding, allowing stronger relationships in families and communities, and incorporating research based knowledge and the land grant university (2000 Programs, n.d.).

The 4-H program has developed into an organization that consists of seven million youth in both urban and rural areas across the United States. Youth in the 4-H 
program are offered a wide variety of opportunities that provide for personal growth. 4-H projects are one of the several methods used to provide growth and life skills to 4- $\mathrm{H}$ members (4-H History Timeline, n.d.). 4-H projects have been an educational way to allow individuals to experience the 4-H program's educational philosophy of 'Learn by Doing' (Lindsay, 1972). The projects allow youth to discover areas of their interest. Projects help develop skills, problem-solving abilities, and reveal career opportunities (West Virginia University Extension Service, 1986). The 4-H program provides opportunities in leadership, communication, technology, and many other areas. These opportunities are provided through several venues in local communities (4-H History Timeline, n.d.).

4-H offers many opportunities for young people. Youth, however, need to become and remain members to benefit from the 4-H experience. Various data over the years has noted concerns about retaining 4-H members. Hartley (1982) found in the Parkersburg (West Virginia) Area that of the 547 first year members, 267 (47.52\%) did not reenroll. In 1985 in Kansas, Astroth noted that between 40 and 50 \% of first year members did not return the following year. Of those members that continued into the second year approximately $20 \%$ did not reenroll in the third year. Ritchie \& Resler (1993) found that youth tended to dropped out of 4-H.

As youth have more opportunities to participate in a growing number of activities, the 4- $\mathrm{H}$ program must find new and innovative ways to increase the number of members and to retain 4-H members. Astroth (1985) found that to retain 4-H members was more difficult than finding new members to enroll. The major factors for leaving 4-H were: project groups did not offer enough for each to be satisfied, youth lacked understanding 
of the program and goals, and youth did not feel a part of the group (Astroth, 1985). In a study about the reenrollment and dropout rates of first year 4-H members, it was determined that the 4-H members who reenrolled participated in more 4-H activities and had more parental support (Hartley, 1982).

\section{Problem Statement}

4-H programs lose many youth each year for a variety of different reasons. A number of youth drop out because they find the program(s) uninteresting. If local programs could retain members longer, the diverse educational experiences offered by 4-H would increase the impact and benefits in the areas of knowledge gained, leadership developed, life skills learned, commitment to community service, and development of personal potential. The dynamics of the program would greatly change if the number of years an individual was involved in 4-H increased. It is important to demonstrate how 4$\mathrm{H}$ can help youth become the type of individuals that young adults strive toward becoming. It is also important to determine the factors that cause students to reenroll in 4-H programs. Determining factors that influence reenrollment in the program would be beneficial for Extension Service planning and program development throughout the country.

\section{Purpose of the Study}

The purpose of the study was to determine retention rates among youth enrolled in West Virginia’s 4-H youth programs and to identify characteristics or trends associated with 4-H member retention. The study explored various factors associated with retention of 4-H members. 
Objectives of the Study

The objectives of the study were:

1. Identify characteristics of youth who were retained as 4-H members.

2. Identify characteristics of youth who failed to remain active in 4-H.

3. Determine trends within characteristics associated with retention of 4-H members.

4. Determine trends within characteristics associated with individuals who failed to remain active in 4-H.

5. Evaluate project subject areas to determine if an association exists between various subject areas and the retention or failure to retain 4- $\mathrm{H}$ members.

Limitation of the Study

This study was limited to information on youth included in the West Virginia 4-H membership database for 2002, 2003, and 2004. The three years are the only years for which data are available in the "official" 4-H plus database. The membership data were self reported by each of the County Extension Offices.

Definitions

The following terms are important to understanding the content of the discussion in the study:

4-H Membership: refers to the fiscal year that a 4-H member is enrolled. The fiscal year is October $1^{\text {st }}$ through the following September $30^{\text {th }}$.

4-H Member: an individual may be enrolled in West Virginia 4-H from the start of the third grade until the individual reaches the age of twenty-one. 


\section{CHAPTER II}

\section{Literature Review}

Information is needed which can help the 4-H program find ways to retain and increase the number of 4-H members enrolled. Youth join 4-H every year, but many do

not continue. Past studies reveal a variety of factors and combinations of factors which may influence a youth’s decision to join or not rejoin 4-H.

\section{Retention Factors}

There are many reasons for youth to enroll in a local community 4-H club or school group. According to one study conducted in West Virginia, 4-H members between the ages of thirteen to eighteen were asked what factors influenced their desire to join a 4-H club. The factors were "it sounds like fun, one of my friends is in it, to meet new friends” (Wingenbach, Nestor, Lawrence, Gartin, Woloshuk, Mulkeen, 2000). Gottlieb, Lewis, and Heinsohn (1974) also noted that individuals found out about 4-H from friends or members.

Another study conducted in West Virginia looked at factors associated with the reenrollment and dropout of first year 4-H members. It was determined that those members who reenrolled had participated in more 4-H activities, had more parental support, and wanted tangible and personal types of recognition. In the nine West Virginia counties included in the study, $75 \%$ of reenrollees did complete a 4-H project, while $76 \%$ of those dropping out did not complete a project. It was found that the percentage of those dropping out increased with the age of first year enrollment and that a small member/leader ratio seemed to improve reenrollment (Hartley 1982). 
Byerley (1972) in a study of ninth and tenth grade girls focused on factors which influenced the decision to be and continue as an active 4- $\mathrm{H}$ member. The following were personal characteristics of girls that stayed in 4-H: grade in school, joined in a lower grade, number of years in 4-H, had plans to attend college, and attended church regularly. There was a significant relationship between a number of family characteristics of the girls who stayed in 4-H. These included: higher educational levels of girls' mothers, mothers were involved in several clubs or organizations, fathers' and mothers' positive attitude when their daughter joined 4- $\mathrm{H}$, and the girls felt their father wanted them to devote more time toward the 4-H program. In the study there was not a significant relationship in the status of membership and the age of the girls, the place of residence, the age of member when first joining, school grades received, girls' dating patterns, parents' marital status, family income, father's educational level, father's occupation, mother's employment outside the home and mother's attitude toward 4-H. A nationwide Texas Agricultural Extension Service study found that 4-H alumni had liked activities, organized clubs and competition (Ladewig \& Thomas (1987). Gottlieb, Lewis, and Heinsohn (1974) also found that 4-Hers were orientated toward enrolling and participating in a multitude of in and out of school activities. 4-Hers, age 13 to 19 , in Ohio noted a substantial relationship of satisfaction with participation, commitment, responsibility, working with younger members, and quality of 4-H meetings. A low relationship of satisfaction was found from advisor participation, project work, peer pressure, and tenure as a 4- $\mathrm{H}$ member. There was found to be no relation between family level of involvement and the difference between urban and rural members (Norland, \& Bennett, (1993). 
In the Ohio study, Norland, and Bennett (1993), found a substantial relationship of member satisfaction from positive parental support and Byerley (1972), Hartley (1982), and Wingenbach et al., (2000) found parental support important in reenrollment.

When looking at ways to encourage 4-Hers to remain in the organization, a study in West Virginia by Wingenbach et al. (2000) indicated that the best retention techniques were Extension Agents and club leaders who were enthusiastic for 4-H. They need to encourage participation in the 4- $\mathrm{H}$ camping program, be motivating, praise youth accomplishments, and provide encouragement to all 4-H members. Hartley (1982) echoed that praise and encouragement to participate are important to get first year members to reenroll. Ritchie and Resler (1993) also determined that the leaders had a crucial role in keeping the members interested, having creative programs and encouraging parental support.

\section{Dropout Factors}

The 4- $\mathrm{H}$ program is an informal educational program where the activities include voluntary learning experiences in which each individual chooses whether to participate (Astroth, 1985). Since 4-H is a voluntary adventure, individuals can also drop out of 4-H for various reasons. The term dropout is defined as a 4-H member that is enrolled for one year and does not reenroll for the following year (Ritchie \& Resler, 1993).

Astroth (1985) noted a major factor of why first year members did not reenroll was a lack of understanding of program, events, and goals. The dropouts did not feel welcome in the group and the project groups did not meet frequently enough to keep them satisfied. Ritchie and Rusler (1993) interviewed youth who had dropped out of 4-H and found their failure to remain active was related to displeasure with the 4-H club, 
being bored at meetings, not enough help with projects, and days were very busy with sports. The Texas Agriculture Extension Service, Heinsohn and Lewis (1995) survey determined that 59 percent of the 4-H alumni had dropped out because they perceived the program was not meeting their interests. The most common reason given by parents for their child's dropping out of 4-H was displeasure with club activities (Wingenbach et al., 2000; Ritchie \& Resler, 1993). When individuals who are not 4-H members were asked why they did not join, most said there were too many things to do (Gottlieb, Lewis, Heinsohn, 1974), or that 4-H was not available to them (Ladewig \& Thomas, 1987). Heinsohn and Lewis (1995) considered 4-H dropout from a developmental perspective. The findings are reflected in the following:

...adolescence is also when individuals need to develop some independence from family. Choosing one’s own activities and dropping some pursued since childhood are ways to do so. Adolescents may even drop activities they like and still enjoy so they can make some choices themselves. Part time jobs offer money and become increasingly available and attractive to adolescents. (\$ 4)

Teen dropout from youth programs could be simply viewed as part of the developmental process (Heinsohn \& Lewis, 1995).

\section{Summary}

There are many reasons why individuals choose to participate in youth organizations including 4-H. Some common reasons for youth joining 4-H clubs were that it would be fun, they would be able to make new friends, they had friends already in 
4-H, and they could participate in activities (Wingenbach et al., 2000; Ladewig \& Thomas, 1987; Hartley 1982).

It was found that the members tended to drop out because the meetings and activities were not interesting, there was not enough help provided with 4-H projects, and individual interests were not being met (Ritchie \& Rusler, 1993; Ladewig \& Thomas, 1987; Wingenbach et al., 2000). Also individuals dropped out of 4-H because they did not feel welcome or did not understand the programs and activities (Astroth, 1985). Heinsohn \& Lewis (1995) considered dropout as part of the developmental process of youth. People that had not been a part of the 4-H program as youth felt that there were too many other things to do and some did not feel the program was available to them (Astroth, 1985; Ladewig \& Thomas, 1987). It was important for 4-H members to have parental support, a strong club leader, and support of Extension staff to insure that 4-H youth continued to grow through the 4-H program (Hartley, 1982; Wingenbach, Meighan, Lawrence, Gartin, Woloshuk, 1999; Norland \& Bennett 1993; Wingenbach et al., 2000). 


\section{CHAPTER III}

Methodology

Purpose of the Study

The purpose of the study was to determine retention rates among youth enrolled in West Virginia’s 4-H youth programs and to identify characteristics or trends associated with 4-H member retention. The study explored various factors associated with retention of 4-H members.

\section{Objectives of the Study}

The objectives of the study were:

1. Identify characteristics of youth who were retained as 4-H members.

2. Identify characteristics of youth who failed to remain active in 4-H.

3. Determine trends within characteristics associated with retention of $4-\mathrm{H}$ members.

4. Determine trends within characteristics associated with individuals who failed to remain active in $4-\mathrm{H}$.

5. Evaluate project subject areas to determine if an association exists between various subject areas and the retention or failure to retain 4- $\mathrm{H}$ members.

\section{Research Design}

This study is considered to be an ex post facto study. The 4-H enrollment data were collected prior to the analysis that was to determine the differences between the characteristics of the data. Ex post facto study looks at past events to identify causes for a particular condition (Patten, 2002). Ex post facto study allows research whose consequence is observable and the problem is to determine the cause that gives reason to the consequence (Ary, Jacobs, Razavieh, 1972). The variables that the study was 
designed around were the 4- $\mathrm{H}$ members that were retained verses those individuals that were not retained and the characteristics associated with each of these variables. Population

The target population of the study consisted of youth enrolled within 4-H clubs in West Virginia's 4-H programs during the years 2002, 2003, and 2004. The accessible population of the study was youth whose information was recorded in West Virginia University Extension Service 4-H Plus membership database for the years of 2002, 2003, and 2004. Membership records were self-reported by West Virginia University County Extension Offices located in each of the 55 West Virginia counties. The accessible population consisted of 36,668 youth representing 55 of the 55 counties in West Virginia.

Because the study utilized official data collected by the West Virginia University Extension Service and the entire accessible population was included in the study, sampling, frame, selection, measurement, and non-response errors were controlled. Instrumentation

The study utilized official data maintained in the West Virginia University Extension Service 4-H Plus membership database. Additional data collection instruments were not required. Because the study relied on official data collected and maintained by the West Virginia University Extension Service, the data were assumed to be valid and reliable. Additional steps were not taken to evaluate the data's content validity or reliability.

\section{Data Collection Procedures}

The study utilized official data maintained in the West Virginia University Extension Service 4-H Plus membership database. The database included the following 
information: member ID number, county, age, gender, grade in school, years in 4-H, participation in leadership activities, participation in parenting activities, Charting pin, 4H All-Star pin, county club, and projects attempted.

The annual data were exported from the official database to an Excel spread sheet. The year was identified and three Excel spreadsheets were merged into one file. The file was imported into the personal computer version of SPSS. The restructure feature of SPSS was used to rearrange the data so that each individual from the three years was represented in a single case with individual data elements maintaining their "year" designation.

Analysis of Data

The data were analyzed to determine those 4- $\mathrm{H}$ members that were retained between 2002 to 2003 as well as those individuals that were retained from 2003 to 2004 . The data were analyzed to determine individual 4-H members that were retained from 2002 to 2004. The number of projects each member attempted during each year was computed into project categories. Then the number of individuals attempting a project in a particular category was computed. Frequencies and means were determined for each of the years of those that were retained or not retained. Discriminate analysis was conducted on those individuals retained and not retained between 2002 and 2004. "Discriminant analysis has two steps: (1) an F test (Wilks' lambda) is used to test if the discriminant model as a whole is significant, and (2) if the F test shows significance, then the individual independent variables are assessed to see which differ significantly in mean by group and these are used to classify the dependent variable” (Discriminant Analysis Function, n.d.). 


\section{Use of Findings}

The study will help provide information about the factors associated with retention of 4-H club members to volunteer leaders, county extension agents, the West Virginia University Extension Service and other extension service around the county. 


\section{CHAPTER IV}

\section{Findings}

\section{Purpose of the Study}

The purpose of the study was to determine retention rates among youth enrolled in West Virginia’s 4-H youth programs and to identify characteristics or trends associated with 4-H member retention. The study explored various factors associated with retention of 4-H members.

\section{Objectives of the Study}

The objectives of the study were:

1. Identify characteristics of youth who were retained as 4-H members.

2. Identify characteristics of youth who failed to remain active in 4-H.

3. Determine trends within characteristics associated with retention of 4-H members.

4. Determine trends within characteristics associated with individuals who failed to remain active in $4-\mathrm{H}$.

5. Evaluate project subject areas to determine if an association exists between various subject areas and the retention or failure to retain 4-H members.

The study utilized official data maintained in the West Virginia University Extension Service 4-H Plus membership database. The target population of the study consisted of youth enrolled within 4-H clubs in West Virginia's 4-H programs during the years 2002, 2003, and 2004. The accessible population of the study was youth whose information was recorded in West Virginia University Extension Service 4-H Plus membership database for the years of 2002, 2003, and 2004. Membership records were self reported by West Virginia University County Extension Offices located in each of 
the 55 West Virginia counties. The accessible population consisted of 36,668 youth representing all of the 55 counties in West Virginia.

The 2002 population consisted of 20,426 members enrolled in the West Virginia 4- $\mathrm{H}$ program, the 2003 enrollment was 18,923 members, and the 16,361 members enrolled in 2004.

Membership by County

The 4-H membership data were reported by each of the 55 County Extension Offices in West Virginia. The county reporting the highest number of 4-H members in 2002 and 2003 was Kanawha County with 1,355 members (6.6\%) in 2002 and 1,078 members (5.7\%) in 2003. In 2004, Berkeley County had the highest number with 661 members (4.0\%) (see Table 1). 
Table 1

4-H Membership by County in West Virginia

\begin{tabular}{|c|c|c|c|c|c|c|}
\hline \multirow[b]{2}{*}{ County } & \multicolumn{2}{|c|}{2002} & \multicolumn{2}{|c|}{2003} & \multicolumn{2}{|c|}{2004} \\
\hline & $\mathrm{N}$ & $\%$ & $\mathrm{~N}$ & $\%$ & $\mathrm{~N}$ & $\%$ \\
\hline Barbour & 205 & 1.0 & 207 & 1.1 & 173 & 1.1 \\
\hline Berkeley & 628 & 3.1 & 632 & 3.3 & 661 & 4 \\
\hline Boone & 73 & 0.4 & 20 & 0.1 & 0.0 & 0.0 \\
\hline Braxton & 147 & 0.7 & 143 & 0.8 & 129 & 0.8 \\
\hline Brooke & 145 & 0.7 & 115 & 0.6 & 132 & 0.8 \\
\hline Cabell & 331 & 1.6 & 440 & 2.3 & 217 & 1.3 \\
\hline Calhoun & 308 & 1.5 & 139 & 0.7 & 115 & 0.7 \\
\hline Clay & 389 & 1.9 & 379 & 2.0 & 285 & 1.7 \\
\hline Doddridge & 132 & 0.6 & 150 & 0.8 & 147 & 0.9 \\
\hline Fayette & 171 & 0.8 & 316 & 1.7 & 221 & 1.4 \\
\hline Gilmer & 274 & 1.3 & 281 & 1.5 & 312 & 1.9 \\
\hline Grant & 210 & 1.0 & 231 & 1.2 & 223 & 1.4 \\
\hline Greenbrier & 678 & 3.3 & 662 & 3.5 & 619 & 3.8 \\
\hline Hampshire & 449 & 2.2 & 492 & 2.6 & 472 & 2.9 \\
\hline Hancock & 158 & 0.8 & 122 & 0.6 & 89 & 0.5 \\
\hline Hardy & 314 & 1.5 & 301 & 1.6 & 293 & 1.8 \\
\hline Harrison & 319 & 1.6 & 416 & 2.2 & 321 & 2.0 \\
\hline Jackson & 825 & 4.0 & 868 & 4.6 & 0.0 & 0.0 \\
\hline Jefferson & 555 & 2.7 & 565 & 3 & 455 & 2.8 \\
\hline Kanawha & 1355 & 6.6 & 1078 & 5.7 & 258 & 1.6 \\
\hline Lewis & 243 & 1.2 & 256 & 1.4 & 230 & 1.4 \\
\hline Lincoln & 348 & 1.7 & 438 & 2.3 & 499 & 3.0 \\
\hline Logan & 945 & 4.6 & 296 & 1.6 & 342 & 2.1 \\
\hline Marion & 243 & 1.2 & 271 & 1.4 & 258 & 1.6 \\
\hline Marshall & 504 & 2.5 & 509 & 2.7 & 512 & 3.1 \\
\hline Mason & 420 & 2.1 & 497 & 2.6 & 523 & 3.2 \\
\hline McDowell & 729 & 3.6 & 156 & 0.8 & 190 & 1.2 \\
\hline Mercer & 750 & 3.7 & 537 & 2.8 & 632 & 3.9 \\
\hline Mineral & 272 & 1.3 & 277 & 1.5 & 289 & 1.8 \\
\hline
\end{tabular}


Table 1 (Continued)

4-H Membership by County in West Virginia

\begin{tabular}{|c|c|c|c|c|c|c|}
\hline \multirow[b]{2}{*}{ County } & \multicolumn{2}{|c|}{2002} & \multicolumn{2}{|c|}{2003} & \multicolumn{2}{|c|}{2004} \\
\hline & $\mathrm{N}$ & $\%$ & $\mathrm{~N}$ & $\%$ & $\mathrm{~N}$ & $\%$ \\
\hline Mingo & 25 & 0.1 & 15 & 0.1 & 166 & 1.0 \\
\hline Monongalia & 264 & 1.3 & 252 & 1.3 & 251 & 1.5 \\
\hline Monroe & 847 & 4.1 & 818 & 4.3 & 759 & 4.6 \\
\hline Morgan & 101 & 0.5 & 112 & 0.6 & 66 & 0.4 \\
\hline Nicholas & 426 & 2.1 & 391 & 2.1 & 382 & 2.3 \\
\hline Ohio & 185 & 0.9 & 142 & 0.8 & 163 & 1.0 \\
\hline Pendleton & 187 & 0.9 & 174 & 0.9 & 164 & 1.0 \\
\hline Pleasants & 198 & 1.0 & 203 & 1.1 & 187 & 1.1 \\
\hline Pocahontas & 213 & 1.0 & 216 & 1.1 & 230 & 1.4 \\
\hline Preston & 397 & 1.9 & 443 & 2.3 & 465 & 2.8 \\
\hline Putnam & 706 & 3.5 & 759 & 4.0 & 792 & 4.8 \\
\hline Raleigh & 732 & 3.6 & 770 & 4.1 & 755 & 4.6 \\
\hline Randolph & 460 & 2.3 & 374 & 2.0 & 395 & 2.4 \\
\hline Ritchie & 136 & 0.7 & 142 & 0.8 & 146 & 0.9 \\
\hline Roane & 207 & 1.0 & 235 & 1.2 & 214 & 1.3 \\
\hline Summers & 246 & 1.2 & 264 & 1.4 & 281 & 1.7 \\
\hline Taylor & 180 & 0.9 & 171 & 0.9 & 182 & 1.1 \\
\hline Tucker & 106 & 0.5 & 94 & 0.5 & 96 & 0.6 \\
\hline Tyler & 68 & 0.3 & 89 & 0.5 & 97 & 0.6 \\
\hline Upshur & 375 & 1.8 & 274 & 1.4 & 254 & 1.6 \\
\hline Wayne & 360 & 1.8 & 630 & 3.3 & 146 & 0.9 \\
\hline Webster & 202 & 1.0 & 227 & 1.2 & 237 & 1.4 \\
\hline Wetzel & 196 & 1.0 & 164 & 0.9 & 154 & 0.9 \\
\hline Wirt & 119 & 0.6 & 126 & 0.7 & 125 & 0.8 \\
\hline Wood & 396 & 1.9 & 410 & 2.2 & 450 & 2.8 \\
\hline Wyoming & 974 & 4.8 & 504 & 2.7 & 513 & 3.1 \\
\hline WV State & 0.0 & 0.0 & 130 & 0.7 & 94 & 0.6 \\
\hline Total & 20426 & & 18923 & & 16361 & \\
\hline
\end{tabular}




\section{Gender of 4-H Members}

The 4-H membership data for 2002 included 9,087 males (44.5\%) and 11,339 females (55.5\%), while in 2003 there were 8,368 males (44.2\%) and 10,555 females (55.8\%). In 2004, the enrollment data recorded 7084 males (43.3\%) and 9,277 females (56.7\%) (see Table 2).

Table 2

Gender of 4-H Members

\begin{tabular}{lcccccc}
\hline 4-H Membership Year & \multicolumn{2}{c}{ Male } & & \multicolumn{2}{c}{ Female } \\
\cline { 2 - 3 } \cline { 5 - 6 } & $N$ & $\%$ & & $N$ & $\%$ \\
\hline 2002 & 9,087 & 44.5 & & 11,339 & 55.5 \\
2003 & 8,368 & 44.2 & & 10,555 & 55.8 \\
2004 & 7,084 & 43.3 & & 9,277 & 56.7 \\
\hline
\end{tabular}

Grade in School, Age, and Years in 4-H

The mean grade in school reported by 4-H members in 2002 was $5.80(S D=$ 2.93). In 2003 there was a mean grade level of $5.97(S D=2.97)$ and in 2004 the mean grade level of 4-H members was $6.08(S D=3.01)$ (see Table 3).

The mean age of 4- $\mathrm{H}$ members in 2002 was 11.93 years $(S D=2.97)$. In 2003 the mean age of 4-H members increased to 12.12 years $(S D=3.03)$. In 2004 the mean age was $12.22(S D=3.05)$ (see Table 3).

The number of years that individuals had been 4- $\mathrm{H}$ members in 2002 had a mean of 2.08 years $(S D=2.51)$. For the membership of year 2003, the mean was 2.92 years $(S D=2.60)$, while in 2004 the mean number of the years 4-Hers have been members increased to 2.99 years $(S D=2.68)$ (see Table 3$)$. 
Table 3

Grade, Age, and Years of 4-H Membership

\begin{tabular}{|c|c|c|c|c|c|c|}
\hline & \multicolumn{2}{|c|}{2002} & \multicolumn{2}{|c|}{2003} & \multicolumn{2}{|c|}{2004} \\
\hline & $M$ & $S D$ & $M$ & $S D$ & $M$ & $S D$ \\
\hline 4-H Member Grade & 5.80 & 2.93 & 5.97 & 2.97 & 6.08 & 3.01 \\
\hline 4-H Member Age & 11.93 & 2.97 & 12.12 & 3.03 & 12.22 & 3.05 \\
\hline $\begin{array}{l}\text { Years of 4-H } \\
\text { Membership }\end{array}$ & 3.01 & 2.51 & 2.92 & 2.60 & 2.99 & 2.68 \\
\hline
\end{tabular}

Years of 4-H Membership

In 2002, 2003 and 2004, first-year members comprised the largest group of 4-H members (see Table 4). Individuals that were second year members made up the second largest group of 4-H members.

\section{Project Enrollment}

The membership data contains the project(s) attempted by each 4-H member during their year of enrollment. The 4-H projects were placed into project categories that were established and listed on the 4-H Membership Enrollment Card. The project categories have related subject matter areas. The 4- $\mathrm{H}$ members can attempt one or more 4- $\mathrm{H}$ projects according to individual interests during a 4- $\mathrm{H}$ year. The "individual and family resource” project category contains five subcategories including "child care”, “clothing”, "personal development”, "management”, and “food preparation” with project data reported on each of the individual subcategories. The subcategory data were used to calculate the data reported under the "individual and family resource" projects category. 
Table 4

Years of 4-H Membership

\begin{tabular}{|c|c|c|c|c|c|c|c|}
\hline \multirow{2}{*}{\multicolumn{2}{|c|}{$\begin{array}{l}\text { Years of 4-H } \\
\text { Membership }\end{array}$}} & \multicolumn{2}{|c|}{2002} & \multicolumn{2}{|c|}{2003} & \multicolumn{2}{|c|}{2004} \\
\hline & & $N$ & $\%$ & $N$ & $\%$ & $N$ & $\%$ \\
\hline 0 & & 264 & 1.3 & 408 & 2.2 & 474 & 2.9 \\
\hline 1 & & 8,603 & 42.1 & 7,476 & 39.5 & 6,581 & 40.2 \\
\hline 2 & & 4,072 & 19.9 & 3,515 & 18.6 & 2,466 & 15.1 \\
\hline 3 & & 2,227 & 10.9 & 2,256 & 11.9 & 1,856 & 11.3 \\
\hline 4 & & 1,342 & 6.6 & 1,356 & 7.2 & 1,374 & 8.4 \\
\hline 5 & & 984 & 4.8 & 970 & 5.1 & 959 & 5.9 \\
\hline 6 & & 757 & 3.7 & 777 & 4.1 & 670 & 4.1 \\
\hline 7 & & 634 & 3.1 & 620 & 3.3 & 558 & 3.4 \\
\hline 8 & & 528 & 2.6 & 482 & 2.5 & 437 & 2.7 \\
\hline 9 & & 387 & 1.9 & 402 & 2.1 & 375 & 2.3 \\
\hline 10 & & 291 & 1.4 & 292 & 1.5 & 274 & 1.7 \\
\hline 11 & & 185 & 0.9 & 197 & 1.0 & 161 & 1.0 \\
\hline 12 & & 95 & 0.5 & 108 & 0.6 & 114 & 0.7 \\
\hline 13 & & 43 & 0.2 & 48 & 0.3 & 50 & 0.3 \\
\hline 14 & & 11 & 0.1 & 11 & 0.1 & 7 & 0.0 \\
\hline 15 & & 1 & 0.0 & 1 & 0.0 & 0 & 0.0 \\
\hline 16 & & 0 & 0.0 & 2 & 0.0 & 1 & 0.0 \\
\hline 17 & & 0 & 0.0 & 0 & 0.0 & 1 & 0.0 \\
\hline 19 & & 0 & 0.0 & 1 & 0.0 & 1 & 0.0 \\
\hline
\end{tabular}


The "miscellaneous" category had the highest number of attempted projects in 2002 with 8,886 4-H projects (28.0\%) (see Table 5). The second highest category was the "individual and family resources" project category with 5,733 projects (18.1\%) attempted and the next highest category was the "animal science" project category with 4,655 projects (14.7\%) undertaken. In 2003 the most projects were attempted in “miscellaneous” category project with 7,258 projects (24.8\%) attempted. The second highest category was the "animal sciences” category with 4,878 projects (16.7\%) attempted and the third highest category was the "individual and family resources" project area with 4,590 projects (15.7\%) undertaken. In 2004 the highest project category was the "miscellaneous" category with 6,287 projects (23.4\%) attempted. The next highest category was the “individual and family resources” with 5,005 projects (18.6\%) attempted and the third highest category was "animal science" with 4,443 projects (16.5\%) attempted. The "plant sciences and crops" category had the lowest number of attempted projects in 2002 with 498 attempted. The "health and safety" category had the lowest number of attempted projects in 2003 with 517 attempted projects and 2003 with 272 attempted projects (see Table 5). 
Table 5

Number of 4-H Projects by Category and Year

\begin{tabular}{|c|c|c|c|c|c|c|}
\hline \multirow[b]{2}{*}{ Project Categories } & \multicolumn{2}{|c|}{2002} & \multicolumn{2}{|c|}{2003} & \multicolumn{2}{|c|}{2004} \\
\hline & $N$ & $\%$ & $N$ & $\%$ & $N$ & $\%$ \\
\hline Animals Science & 4,655 & 14.7 & 4,878 & 16.7 & 4,443 & 16.5 \\
\hline Communication Art and Sciences & 947 & 3.0 & 1,338 & 4.6 & 952 & 3.5 \\
\hline Individual and Family Resources & 5,733 & 18.1 & 4,590 & 15.7 & 5,005 & 18.6 \\
\hline Child Care & 2,438 & 7.7 & 2,034 & 7.0 & 2,476 & 9.2 \\
\hline Clothing & 296 & 0.9 & 312 & 1.1 & 520 & 1.9 \\
\hline Personal Development & 647 & 2.0 & 1,309 & 4.5 & 733 & 2.7 \\
\hline Management & 273 & 0.9 & 178 & 0.6 & 250 & 0.9 \\
\hline Food Preparation & 1,628 & 5.1 & 1,477 & 5.1 & 1,618 & 6.0 \\
\hline Health and Safety & 517 & 1.6 & 306 & 1.0 & 272 & 1.0 \\
\hline $\begin{array}{l}\text { Leadership and Community } \\
\text { Involvement }\end{array}$ & 618 & 1.9 & 1047 & 3.6 & 401 & 1.5 \\
\hline Leisure and Cultural Education & 904 & 2.9 & 908 & 3.1 & 898 & 3.3 \\
\hline Mechanical Sciences & 1,859 & 5.9 & 1,644 & 5.6 & 1,412 & 5.2 \\
\hline Miscellaneous & 8,886 & 28.0 & 7,258 & 24.8 & 6,287 & 23.4 \\
\hline Natural Resources and Environment & 1,808 & 5.7 & 1,604 & 5.5 & 1,364 & 5.1 \\
\hline Plant Sciences and Crops & 498 & 1.6 & 342 & 1.2 & 292 & 1.1 \\
\hline Total & 31,707 & 100 & 29,225 & 100 & 26,923 & 100 \\
\hline
\end{tabular}

Retention of 4-H Members

There were 10,056 of the members in 2002 (49.2\%) continued their memberships into 2003 (see Table 6). There were 10,370 of the 2002 members (50.8\%) who did not 
continue as 4-H members into 2003. From 2003 to 2004 8,737 members (46.2\%)

retained their 4-H memberships. There were 10,186 individual members (53.8\%) that dropped out during the same time period. The number of 4-H members that joined in 2002 and continued their membership through 2004 was 6,023 members (29.5\%) (see Table 6). There were 249 individuals who joined 4-H in 2002, discontinued their membership in 2003, and then rejoined the program in 2004 (see Table 6).

Table 6

Retention Rates

\begin{tabular}{|c|c|c|c|c|c|c|c|c|c|}
\hline \multirow[b]{2}{*}{$\begin{array}{l}\text { Membership } \\
\text { Year }\end{array}$} & \multicolumn{2}{|c|}{$\begin{array}{l}\text { Not Retained } \\
1^{\text {st }} \text { Year }\end{array}$} & \multicolumn{2}{|c|}{$\begin{array}{c}\text { Retained } 1^{\text {st }} \\
\text { Year }\end{array}$} & \multicolumn{2}{|c|}{$\begin{array}{l}\text { Retained } 2^{\text {nd }} \\
\text { Year }\end{array}$} & \multicolumn{2}{|c|}{$\begin{array}{c}\text { Skipped } 1^{\text {st }} \\
\text { Year } \\
\text { Reenrolled } \\
2^{\text {nd }} \text { Year } \\
\end{array}$} & \multirow[t]{2}{*}{$\begin{array}{c}\text { Total } \\
\text { Member }\end{array}$} \\
\hline & $N$ & $\%$ & $N$ & $\%$ & $N$ & $\%$ & $N$ & $\%$ & \\
\hline $2002-2003$ & 10,370 & 50.8 & 10,056 & 49.2 & 6,023 & 29.5 & 249 & 0.7 & 20,426 \\
\hline 2003-2004 & 10,186 & 53.8 & 8,737 & 46.2 & NA & NA & NA & NA & 18,923 \\
\hline
\end{tabular}

4-H Member Years of Membership, Age, and Grade Level, and Retention

The membership data indicates that the largest number of 4-H members who were retained between 2002 and 2003 were the first year members ( $n=3,068,30.5 \%)$ and the second largest group were second year members $(n=1,818,18.1 \%)$. This was similar to the membership data from 2003 to 2004 when the largest number of retained members were first year members ( $n=2,248,25.7 \%)$. First years members also comprised the largest group of individuals who that dropped out between 2002 and 2003 and between 2003 and 2004 (see Table 7). 
The age groups of 4- $\mathrm{H}$ members who were retained from 2002 to 2003 were examined. The largest age group retained was 10 year olds, with 1,522 members (15.2\%) (see Table 8). Ten years olds were also found to be the largest group retained between 2003 and 2004 with 1,299 members (14.1\%). Of those individuals that did not continue their membership from 2002 to 2003, the most individuals who dropped out were from the 10 year-old age group which consisted of 2,313 individuals (22.4\%). However between 2003 and 2004 the largest number of dropouts was in the 11 year old category with 2,238 individuals (22.0\%) (see Table 8).

When the grade level of members who were retained from 2002 to 2003 were examined, the largest group retained was those in the 4th grade with 1,584 members retained (15.8\%). A similar scenario occurred with those retained from 2003 to 2004 when the largest group $(n=1,315,15.1 \%)$ was comprised of individuals in the 4 th grade. Fourth graders ( $n=2,762,26.6 \%)$ comprised the largest group that dropped out between 2002 and 2003. Of those members who did not continue between 2003 and 2004, 2666 individuals (26.6\%) were 4th graders (see Table 9). 
Table 7

\section{Comparison of Years of Membership and Retention}

\begin{tabular}{|c|c|c|c|c|c|c|c|c|}
\hline \multirow[t]{3}{*}{ Year 4-H Membership } & \multicolumn{4}{|c|}{ Member Not Retained } & \multicolumn{4}{|c|}{ Member Retained } \\
\hline & \multicolumn{2}{|c|}{$2002-2003$} & \multicolumn{2}{|c|}{ 2003-2004 } & \multicolumn{2}{|c|}{$2002-2003$} & \multicolumn{2}{|c|}{ 2003-2004 } \\
\hline & $N$ & $\%$ & $N$ & $\%$ & $N$ & $\%$ & $N$ & $\%$ \\
\hline 0 & 110 & 1.1 & 212 & 2.1 & 154 & 1.5 & 196 & 2.2 \\
\hline 1 & 5,535 & 53.4 & 5,228 & 51.3 & 3,068 & 30.5 & 2,248 & 25.7 \\
\hline 2 & 2,254 & 21.7 & 1,841 & 18.1 & 1,818 & 18.1 & 1,674 & 19.2 \\
\hline 3 & 948 & 9.1 & 1,043 & 10.2 & 1,279 & 12.7 & 1,213 & 13.9 \\
\hline 4 & 421 & 4.1 & 477 & 4.7 & 921 & 9.2 & 879 & 10.1 \\
\hline 5 & 255 & 2.5 & 328 & 3.2 & 729 & 7.2 & 642 & 7.3 \\
\hline 6 & 178 & 1.7 & 239 & 2.3 & 579 & 5.8 & 538 & 6.2 \\
\hline 7 & 148 & 1.4 & 193 & 1.9 & 486 & 4.8 & 427 & 4.9 \\
\hline 8 & 131 & 1.3 & 145 & 1.4 & 397 & 3.9 & 337 & 3.9 \\
\hline 9 & 122 & 1.2 & 148 & 1.5 & 265 & 2.6 & 254 & 2.9 \\
\hline 10 & 106 & 1.0 & 126 & 1.2 & 185 & 1.8 & 166 & 1.9 \\
\hline 11 & 70 & 0.7 & 91 & 0.9 & 115 & 1.1 & 106 & 1.2 \\
\hline 12 & 51 & 0.5 & 62 & 0.6 & 44 & 0.4 & 46 & 0.5 \\
\hline 13 & 30 & 0.3 & 43 & 0.4 & 13 & 0.1 & 5 & 0.1 \\
\hline 14 & 9 & 0.1 & 8 & 0.1 & 2 & 0.0 & 3 & 0.0 \\
\hline 15 & 0 & 0.0 & 1 & 0.0 & 1 & 0.0 & 0 & 0.0 \\
\hline 16 & 0 & 0.0 & 0 & 0.0 & 0 & 0.0 & 2 & 0.0 \\
\hline 19 & 0 & 0.0 & 0 & 0.0 & 0 & 0.0 & 1 & 0.0 \\
\hline Total & 10,368 & 100.0 & 10,185 & 100.0 & 10,056 & 100.0 & 8,737 & 100.0 \\
\hline
\end{tabular}


Table 8

\section{Comparison of Age of 4-H Member and Retention}

\begin{tabular}{|c|c|c|c|c|c|c|c|c|}
\hline \multirow[t]{3}{*}{ Age 4-H Membership } & \multicolumn{4}{|c|}{ Member Not Retained } & \multicolumn{4}{|c|}{ Member Retained } \\
\hline & \multicolumn{2}{|c|}{$2002-2003$} & \multicolumn{2}{|c|}{$2003-2004$} & \multicolumn{2}{|c|}{$2002-2003$} & \multicolumn{2}{|c|}{$2003-2004$} \\
\hline & $N$ & $\%$ & $N$ & $\%$ & $N$ & $\%$ & $N$ & $\%$ \\
\hline 1 & 1 & 0.0 & 0 & 0.0 & 0 & 0.0 & 0 & 0.0 \\
\hline 3 & 1 & 0.0 & 0 & 0.0 & 0 & 0.0 & 2 & 0.0 \\
\hline 4 & 1 & 0.0 & 5 & 0.0 & 4 & 0.0 & 4 & 0.0 \\
\hline 5 & 46 & 0.4 & 56 & 0.6 & 26 & 0.3 & 24 & 0.3 \\
\hline 6 & 151 & 1.5 & 114 & 1.1 & 159 & 1.6 & 152 & 1.7 \\
\hline 7 & 218 & 2.1 & 175 & 1.7 & 203 & 2.0 & 220 & 2.5 \\
\hline 8 & 325 & 3.1 & 314 & 3.1 & 423 & 4.2 & 318 & 3.6 \\
\hline 9 & 857 & 8.3 & 619 & 6.1 & 1,067 & 10.6 & 894 & 10.2 \\
\hline 10 & 2,313 & 22.4 & 2,105 & 20.7 & 1,522 & 15.2 & 1,229 & 14.1 \\
\hline 11 & 2,171 & 21.0 & 2,238 & 22.0 & 1,390 & 13.8 & 1,119 & 12.8 \\
\hline 12 & 1,456 & 14.1 & 1,339 & 13.2 & 1,115 & 11.1 & 974 & 11.2 \\
\hline 13 & 694 & 6.7 & 766 & 7.5 & 1,001 & 10.0 & 891 & 10.2 \\
\hline 14 & 553 & 5.3 & 618 & 6.1 & 802 & 8.0 & 780 & 8.9 \\
\hline 15 & 345 & 3.3 & 420 & 4.1 & 676 & 6.7 & 628 & 7.2 \\
\hline 16 & 338 & 3.3 & 359 & 3.5 & 622 & 6.2 & 557 & 6.4 \\
\hline 17 & 288 & 2.8 & 343 & 3.4 & 450 & 4.5 & 430 & 4.9 \\
\hline 18 & 273 & 2.6 & 303 & 3.0 & 301 & 3.0 & 250 & 2.9 \\
\hline
\end{tabular}


Table 8 (Continued)

Comparison of Age of 4-H Member and Retention

\begin{tabular}{lrrrrrrrr}
\hline Age 4-H Membership & \multicolumn{3}{c}{ Member Not Retained } & \multicolumn{3}{c}{ Member Retained } \\
& \multicolumn{2}{c}{$2002-2003$} & \multicolumn{2}{c}{ 2003-2004 } & \multicolumn{2}{c}{$2002-2003$} & \multicolumn{2}{c}{$2003-2004$} \\
\cline { 2 - 9 } & \multicolumn{1}{c}{$N$} & \multicolumn{1}{c}{$N$} & $\%$ & $N$ & $\%$ & $N$ & $\%$ \\
\hline 19 & 155 & 1.5 & 183 & 1.8 & 185 & 1.8 & 166 & 1.9 \\
20 & 90 & 0.9 & 119 & 1.2 & 89 & 0.9 & 85 & 1.0 \\
21 & 63 & 0.6 & 88 & 0.9 & 9 & 0.1 & 9 & 0.1 \\
22 & 6 & 0.1 & 8 & 0.1 & 1 & 0.0 & 1 & 0.0 \\
23 & 2 & 0.0 & 1 & 0.0 & 1 & 0.0 & 0 & 0.0 \\
24 & 0 & 0.0 & 1 & 0.0 & 0 & 0.0 & 0 & 0.0 \\
Total & 10,347 & 100.0 & 10,174 & 100.0 & 10,046 & 100.0 & 8,733 & 100.0 \\
\hline
\end{tabular}


Table 9

Comparison of Grade Level of 4-H Member and Retention

\begin{tabular}{lcccccccc}
\hline Grade Level of the Member & \multicolumn{3}{c}{ Member Not Retained } & \multicolumn{3}{c}{ Member Retained } \\
& $2002-2003$ & $2003-2004$ & $2002-2003$ & $2003-2004$ \\
& $N$ & $\%$ & $N$ & $\%$ & $N$ & $\%$ & $N$ & $\%$ \\
\hline 0 & 170 & 1.6 & 166 & 1.6 & 179 & 1.8 & 167 & 1.9 \\
1 & 245 & 2.4 & 189 & 1.9 & 228 & 2.3 & 224 & 2.6 \\
2 & 343 & 3.3 & 328 & 3.2 & 438 & 4.4 & 358 & 4.1 \\
3 & 974 & 9.4 & 660 & 6.5 & 1,183 & 11.8 & 940 & 10.8 \\
4 & 2,762 & 26.6 & 2,666 & 26.2 & 1,584 & 15.8 & 1,315 & 15.1 \\
5 & 2,184 & 21.1 & 2,125 & 20.9 & 1,296 & 12.9 & 1,082 & 12.4 \\
6 & 1,077 & 10.4 & 1,043 & 10.2 & 1,077 & 10.7 & 958 & 11.0 \\
7 & 564 & 5.4 & 653 & 6.4 & 1,002 & 10.0 & 857 & 9.8 \\
8 & 498 & 4.8 & 596 & 5.9 & 788 & 7.8 & 782 & 9.0 \\
9 & 360 & 3.5 & 411 & 4.0 & 687 & 6.8 & 609 & 7.0 \\
10 & 296 & 2.9 & 349 & 3.4 & 578 & 5.7 & 570 & 6.5 \\
11 & 304 & 2.9 & 330 & 3.2 & 460 & 4.6 & 401 & 4.6 \\
12 & 357 & 3.4 & 339 & 3.3 & 340 & 3.4 & 234 & 2.7 \\
13 & 152 & 1.5 & 257 & 2.5 & 172 & 1.7 & 202 & 2.3 \\
14 & 78 & 0.8 & 66 & 0.6 & 40 & 0.4 & 31 & 0.4 \\
15 & 6 & 0.1 & 8 & 0.1 & 3 & 0.0 & 7 & 0.1 \\
18 & 0 & 0.0 & 0 & 0.0 & 1 & 0.0 & 0 & 0.0 \\
Total & 10,370 & 100 & 10,186 & 100 & 10,056 & 100 & 8,737 & 100 \\
\hline
\end{tabular}


Gender of 4-H Members and Membership Retention

Individuals retained between 2002 and 2003 consisted of 4,229 males (42.1\%) and 5,827 females (57.9\%) (see Table 11). Individuals retained from 2003 to 2004 included 3,579 males (41.0\%) and 5158 females (59.0\%), while from 2002 to 2004, 2,404 males (39.9\%) and 3,619 females (60.1\%) were retained. Those individuals that did not continue between 2002 to 2003 and 2003 to 2004 were found to have a similar breakdown between males and females, which is shown in Table 10 .

Table 10

Comparison of Gender of 4-H Member and Retention

\begin{tabular}{|c|c|c|c|c|c|c|c|c|c|c|}
\hline \multirow[t]{3}{*}{ Gender } & \multicolumn{4}{|c|}{ Member Not Retained } & \multicolumn{6}{|c|}{ Member Retained } \\
\hline & \multicolumn{2}{|c|}{$2002-2003$} & \multicolumn{2}{|c|}{ 2003-2004 } & \multicolumn{2}{|c|}{ 2002-2003 } & \multicolumn{2}{|c|}{ 2003-2004 } & \multicolumn{2}{|c|}{ 2002-2004 } \\
\hline & $N$ & $\%$ & $N$ & $\%$ & $N$ & $\%$ & $N$ & $\%$ & $N$ & $\%$ \\
\hline Male & 4,858 & 46.8 & 4,789 & 47 & 4,229 & 42.1 & 3,579 & 41 & 2,404 & 39.9 \\
\hline Female & 5,512 & 53.2 & 5,397 & 53 & 5,827 & 57.9 & 5,158 & 59 & 3,619 & 60.1 \\
\hline Total & 10,370 & 100 & 10,186 & 100 & 10,056 & 100 & 8,737 & 100 & 6,023 & 100 \\
\hline
\end{tabular}

Mean Age, Grade and Years of Membership of those Retained and Not Retained

The 4-H members retained from 2002 to 2003 had a mean age of 12.18 years $(S D=3.06)$ and mean grade level of 6.09 years $(S D=3.03)$. The mean number of years these individuals were members of the $4-\mathrm{H}$ program was 3.40 years $(S D=2.67)$. This was consistent with those individuals that were retained from 2003 to 2004 . The mean number of years these individuals were members of $4-\mathrm{H}$ was 3.51 years $(S D=2.68)$. The 4-H members that were retained between 2002 and 2004 had a mean age of 12.05 years $(S D=2.93)$ and a mean grade level of 6.01 years $(S D=2.93)$. The mean number of years 
an individual had been in the program was 3.56 years with a standard deviation of 2.58 (see Table 11).

Table 11

Mean Age, Grade and Years of Membership with Retention

\begin{tabular}{|c|c|c|c|c|c|c|c|c|c|}
\hline & \multicolumn{3}{|c|}{ Age } & \multicolumn{3}{|c|}{ Grade } & \multicolumn{3}{|c|}{ Years of Membership } \\
\hline & $M$ & $S D$ & $N$ & $M$ & $S D$ & $N$ & $M$ & $S D$ & $N$ \\
\hline \multicolumn{10}{|l|}{ 2002-2003 } \\
\hline Not Retained & 11.68 & 2.86 & 10,347 & 5.52 & 2.80 & 10,370 & 2.22 & 2.20 & 10,368 \\
\hline Retained & 12.18 & 3.06 & 10,046 & 6.09 & 3.03 & 10,056 & 3.40 & 2.67 & 10,056 \\
\hline \multicolumn{10}{|l|}{ 2003-2004 } \\
\hline Not Retained & 11.98 & 2.97 & 10,174 & 5.79 & 2.88 & 10,186 & 2.41 & 2.42 & 10,185 \\
\hline Retained & 12.27 & 3.10 & 8,733 & 6.18 & 3.05 & 8,737 & 3.51 & 2.68 & 8,737 \\
\hline \multicolumn{10}{|l|}{ Retained Two } \\
\hline Years: 2002-2004 & 12.05 & 2.93 & 6,023 & 6.01 & 2.93 & 6,023 & 3.56 & 2.58 & 6,023 \\
\hline
\end{tabular}

Individuals that were not retained 2002 to 2003 had a mean age of 11.68 (SD = 2.86), a mean grade level of $5.52(S D=2.80)$, and had been a member of $4-\mathrm{H}$ an average of 2.22 years $(S D=2.20)$. Individuals that did not continue from 2003 to 2004 had a mean age of 11.98 years of $4-\mathrm{H}$ membership $(S D=2.97)$, the mean grade level of 5.79 $(S D=2.88)$ and a mean of 2.41 years of $4-\mathrm{H}$ membership $(S D=2.24)$ (see Table 11$)$. Number of Members Retained who Attempted at least one Project from a given Project Category

The number of members that attempted at least one project from a particular project category was examined for members that were retained from 2002 to 2004. More members attempted at least one project from the "animal science” project category during 
2002, 2003, and 2004 than any other project category (see Table 12). During these years females were more likely to attempt at least one "animal science" project than males. In 2002 the second highest project category was “miscellaneous” followed by “individual and family resources”. Female members were more likely to attempt a project in both categories than males. The second highest project category in 2003 and 2004 was “individual and family resources” followed by “miscellaneous” projects and again females were more likely to have attempted a project from the "individual and family resources" and "miscellaneous" category than males (see Table 12).

Of the members that attempted at least one project from a particular project category that were retained from 2002 to 2003, more members attempted at least one project from the "animal science" project category (see Table 13). This was followed by the "miscellaneous" project category and then "individual and family resources". In each of the three project categories there were a higher number of females attempting at least one project in each of the categories than males (see Table 13).

Those individuals that did not continue between 2002 and 2003 had more members who attempted at least one project from the "miscellaneous" projects category. The next highest category to have members attempting at least one project was “individual and family resources" followed "animal science”. In each of these categories, there was a slightly higher number of females attempted a project in each of the categories than males (see Table 13). 
Table 12

Number of Members Retained for 2002 to 2004 Who Attempted at Least One Project from a Given Project Category

\begin{tabular}{|c|c|c|c|c|c|c|c|c|c|c|c|}
\hline \multirow[b]{2}{*}{ Project Categories } & \multicolumn{4}{|c|}{2002} & \multicolumn{4}{|c|}{2003} & \multicolumn{3}{|c|}{2004} \\
\hline & $\begin{array}{c}\text { Number } \\
\text { of } \\
\text { members }\end{array}$ & Male & Female & $\begin{array}{c}\text { Number } \\
\text { of } \\
\text { members }\end{array}$ & Male & Female & $\begin{array}{l}\text { Rank } \\
\text { Order } \\
2003 \\
\end{array}$ & $\begin{array}{c}\text { Number } \\
\text { of } \\
\text { members }\end{array}$ & Male & Female & $\begin{array}{c}\text { Rank } \\
\text { Order } \\
2004 \\
\end{array}$ \\
\hline Animals Science & 2,404 & 954 & 1,450 & 2,602 & 1,019 & 1,583 & 1 & 2,437 & 966 & 1,471 & 1 \\
\hline Miscellaneous & 1,895 & 745 & 1,150 & 1,254 & 507 & 747 & 3 & 1,088 & 436 & 652 & 3 \\
\hline $\begin{array}{l}\text { Individual and Family } \\
\text { Resources }\end{array}$ & 1,495 & 393 & 1,102 & 1,490 & 381 & 1,109 & 2 & 1,750 & 513 & 1,237 & 2 \\
\hline Child Care & 1,180 & 249 & 931 & 1,143 & 215 & 928 & & 1,353 & 317 & 1,036 & \\
\hline Food Preparation & 827 & 190 & 637 & 848 & 174 & 674 & & 873 & 204 & 669 & \\
\hline Personal Development & 310 & 127 & 183 & 321 & 132 & 189 & & 348 & 133 & 215 & \\
\hline Clothing & 177 & 8 & 169 & 175 & 12 & 163 & & 246 & 47 & 199 & \\
\hline Management & 104 & 38 & 66 & 105 & 43 & 62 & & 191 & 73 & 118 & \\
\hline Mechanical Sciences & 771 & 513 & 258 & 737 & 496 & 241 & 4 & 681 & 462 & 219 & 4 \\
\hline $\begin{array}{l}\text { Natural Resources and } \\
\text { Environment }\end{array}$ & 706 & 376 & 330 & 695 & 362 & 333 & 5 & 661 & 341 & 320 & 5 \\
\hline $\begin{array}{l}\text { Leisure and Cultural } \\
\text { Education }\end{array}$ & 416 & 171 & 245 & 506 & 203 & 303 & 7 & 593 & 229 & 364 & 6 \\
\hline $\begin{array}{l}\text { Communication Art and } \\
\text { Sciences }\end{array}$ & 391 & 96 & 295 & 621 & 194 & 427 & 6 & 551 & 187 & 364 & 7 \\
\hline
\end{tabular}


Table 12 (Continued)

Number of Members Retained for 2002 to 2004 Who Attempted at Least One Project from a Given Project Category

\begin{tabular}{|c|c|c|c|c|c|c|c|c|c|c|c|}
\hline \multirow[b]{2}{*}{ Project Categories } & \multicolumn{4}{|c|}{2002} & \multicolumn{4}{|c|}{2003} & \multicolumn{3}{|c|}{2004} \\
\hline & $\begin{array}{c}\text { Number } \\
\text { of } \\
\text { members }\end{array}$ & Male & Female & $\begin{array}{c}\text { Number } \\
\text { of } \\
\text { members }\end{array}$ & Male & Female & $\begin{array}{c}\text { Rank } \\
\text { Order } \\
2003\end{array}$ & $\begin{array}{c}\text { Number } \\
\text { of } \\
\text { members }\end{array}$ & Male & Female & $\begin{array}{c}\text { Rank } \\
\text { Order } \\
2004\end{array}$ \\
\hline $\begin{array}{l}\text { Leadership and Community } \\
\text { Involvement }\end{array}$ & 269 & 98 & 171 & 429 & 186 & 243 & 8 & 247 & 77 & 170 & 8 \\
\hline Health and Safety & 210 & 72 & 138 & 135 & 26 & 109 & 10 & 169 & 48 & 121 & 10 \\
\hline Plant Sciences and Crops & 207 & 67 & 140 & 184 & 58 & 126 & 9 & 176 & 61 & 115 & 9 \\
\hline
\end{tabular}


Table 13

Number of Members Retained or Not Retained for 2002 to 2003 Who Attempted at Least One Project from a Given Project Category

\begin{tabular}{|c|c|c|c|c|c|c|c|}
\hline \multirow[b]{2}{*}{ Project Categories } & \multicolumn{3}{|c|}{ Not Retained } & \multicolumn{4}{|c|}{ Retained } \\
\hline & $\begin{array}{c}\text { Number of } \\
\text { members }\end{array}$ & Male & Female & $\begin{array}{c}\text { Number of } \\
\text { members }\end{array}$ & Male & Female & Rank Order \\
\hline Miscellaneous & 5,497 & 2,617 & 2,880 & 3,389 & 1,403 & 1,986 & 2 \\
\hline Individual and Family Resources & 3,333 & 1,534 & 1,799 & 2,400 & 739 & 1,661 & 3 \\
\hline Child Care & 7,65 & 243 & 522 & 1,673 & 378 & 1,295 & \\
\hline Food Preparation & 470 & 150 & 320 & 1,158 & 273 & 885 & \\
\hline Personal Development & 170 & 81 & 89 & 477 & 201 & 276 & \\
\hline Management & 113 & 45 & 68 & 160 & 62 & 98 & \\
\hline Clothing & 67 & 10 & 57 & 229 & 12 & 217 & \\
\hline Animals Science & 1,100 & 445 & 655 & 3,555 & 1,435 & 2,120 & 1 \\
\hline Natural Resources and Environment & 671 & 390 & 281 & 1,137 & 624 & 513 & 5 \\
\hline Mechanical Sciences & 649 & 413 & 236 & 1,210 & 813 & 397 & 4 \\
\hline Communication Art and Sciences & 341 & 101 & 240 & 606 & 161 & 445 & 7 \\
\hline Leisure and Cultural Education & 273 & 121 & 152 & 631 & 252 & 379 & 6 \\
\hline Leadership and Community Involvement & 220 & 93 & 127 & 398 & 149 & 249 & 8 \\
\hline Health and Safety & 211 & 80 & 131 & 306 & 114 & 192 & 10 \\
\hline Plant Sciences and Crops & 191 & 77 & 114 & 307 & 106 & 201 & 9 \\
\hline
\end{tabular}


The number of members that attempted a least one project from a particular project category that were retained from 2003 to 2004 had more members attempting projects from the "animal science" project category. This was followed by the "miscellaneous" project category and then "individual and family resource” category. In each of the three project categories a higher number of females attempted a project than males. Of members not retained from 2003 to 2004 more attempted least one project in the "miscellaneous" category. Next was 'individual and family resources" followed “animal science”. Each of these categories of individuals that did not continue had a slightly higher number of females who attempted least one a project in each of the categories than males (see Table 14). 
Table 14

Number of Members Retained and Not Retained for 2003 to 2004 Who Attempted at Least One Project from a Given Project Category

\begin{tabular}{|c|c|c|c|c|c|c|c|}
\hline \multirow[b]{2}{*}{ Project Categories } & \multicolumn{3}{|c|}{ Not Retained } & \multicolumn{4}{|c|}{ Retained } \\
\hline & $\begin{array}{l}\text { Number of } \\
\text { members }\end{array}$ & Male & Female & $\begin{array}{l}\text { Number of } \\
\text { members }\end{array}$ & Male & Female & Rank Order \\
\hline Miscellaneous & 4,427 & 2,074 & 2,353 & 2,831 & 1,165 & 1,666 & 2 \\
\hline Individual and Family Resources & 2,660 & 1,199 & 1,461 & 1,930 & 564 & 1,366 & 3 \\
\hline Animals Science & 1,647 & 662 & 985 & 3,231 & 1,272 & 1,959 & 1 \\
\hline Personal Development & 758 & 385 & 373 & 551 & 250 & 301 & \\
\hline Child Care & 715 & 153 & 562 & 1,319 & 256 & 1,063 & \\
\hline Food Preparation & 497 & 123 & 374 & 980 & 209 & 771 & \\
\hline Clothing & 111 & 11 & 100 & 201 & 15 & 186 & \\
\hline Management & 62 & 24 & 38 & 116 & 47 & 69 & \\
\hline Natural Resources and Environment & 708 & 405 & 303 & 896 & 486 & 410 & 5 \\
\hline Mechanical Sciences & 668 & 471 & 197 & 976 & 667 & 309 & 4 \\
\hline Communication Art and Sciences & 619 & 256 & 363 & 719 & 217 & 502 & 6 \\
\hline Leadership and Community Involvement & 461 & 227 & 234 & 586 & 269 & 317 & 7 \\
\hline Leisure and Cultural Education & 344 & 151 & 193 & 564 & 230 & 334 & 8 \\
\hline Health and Safety & 147 & 42 & 105 & 159 & 32 & 127 & 10 \\
\hline Plant Sciences and Crops & 130 & 53 & 77 & 212 & 74 & 138 & 9 \\
\hline
\end{tabular}




\section{Discriminant Analysis}

A stepwise discriminant analysis statistical procedure was used to determine if the difference could be established between retainees (2002-2004) and non-retainees (20022004) on key components of the study. Because there were only two independent groups, the discriminant analysis procedure resulted in only one discriminant function. The null hypothesis tested was that in the population there would be no difference between the group centroids on discriminant score.

The discriminant analysis produced a chi-square value that was found to be significant $(\alpha \leq .05)$. The null hypothesis was rejected. There was a difference between the group centroids on the discriminant score.

A Wilks' lambda value of .84 indicated that $84 \%$ of the variance was unexplained. Structure coefficients are considered when the absolute value is greater than or equal to .30 (Hair, et al., 1995). The variables that had a high structure coefficient was "animal science” project ( $\mathrm{s}=0.57)$, years $4-\mathrm{H}$ membership $(\mathrm{s}=0.45)$, “child care” project area (s $=0.34)$, and "food preparation" project area $(\mathrm{s}=0.32)$ shown in Table 15. The standardized canonical discriminant coefficients (b) the absolute value should not be less then one half of the largest value to be used in the discriminant function (Hair, et al., 1995). The variables that influence the discriminant function were age $(b=-.71)$, years of 4-H membership ( $\mathrm{b}=.71)$, “individual and family resource” project area $(\mathrm{b}=-.62)$, "animal science" projects area $(\mathrm{b}=.53)$, and "child care" project area $(\mathrm{b}=.50)$ (see Table 16). The discriminant function accounted for $20 \%(\mathrm{Rc}=0.41)$ of the variance which can be explained by the two groups. The eigenvalue .20 shows that the discriminant function 
can explain 20 times as much as is not being explained. The classification of cases reported determined that $70 \%$ were classified correctly (see Table 16).

Table 15

Summary of the Discriminant Analysis for 2002 to 2004

Discriminant Function 1

\begin{tabular}{|c|c|c|}
\hline Variables & Group $_{b}$ & $s^{c}$ \\
\hline Animal Science Project Category & 0.53 & 0.57 \\
\hline Years of $4 \mathrm{H}$ Memberships & 0.71 & 0.45 \\
\hline Child Care Project Category & 0.50 & 0.34 \\
\hline Food Preparation Project Category & 0.27 & 0.32 \\
\hline Clothing Project Category & 0.13 & 0.18 \\
\hline Leisure and Cultural Education Project Category & 0.09 & 0.18 \\
\hline $\begin{array}{l}\text { Natural Resources and Environment Project } \\
\text { Category }^{\mathrm{a}}\end{array}$ & & 0.17 \\
\hline Mechanical Sciences Project Category & 0.15 & 0.17 \\
\hline Personal Development Project Category & 0.36 & 0.16 \\
\hline Communication Art and Sciences & 0.11 & 0.13 \\
\hline Leadership and Community Involvement & 0.09 & 0.12 \\
\hline Grade Level $^{\mathrm{a}}$ & & 0.11 \\
\hline Health and Safety Project Category & 0.05 & 0.09 \\
\hline Leadership Activities & 0.05 & 0.07 \\
\hline Plant Sciences and Crops Project Category & -0.06 & 0.07 \\
\hline Charting Program $^{\mathrm{a}}$ & & 0.07 \\
\hline Age & -0.71 & 0.06 \\
\hline
\end{tabular}


Table 15 (Continued)

Summary of the Discriminant Analysis for 2002 to 2004

Discriminant Function 1

\begin{tabular}{|c|c|c|}
\hline Variables & Groupb $_{b}$ & $\mathrm{~s}^{\mathrm{c}}$ \\
\hline Management Project Category ${ }^{\mathrm{a}}$ & & 0.05 \\
\hline Parenting Activities $^{\mathrm{a}}$ & & 0.01 \\
\hline 4 H All-Star & -0.04 & -0.02 \\
\hline Individual and Family Resources Project Category & -0.62 & -0.06 \\
\hline Miscellaneous Project Category & 0.06 & -0.25 \\
\hline Eigenvalue & 0.20 & \\
\hline $\mathrm{Rc}^{\mathrm{d}}$ & 0.41 & \\
\hline Wilks' Lambda & 0.84 & \\
\hline \multicolumn{3}{|l|}{ Centroids } \\
\hline Not Enrolled for Two Years & -0.29 & \\
\hline Retained for Two Years. & 0.69 & \\
\hline
\end{tabular}

Table 16

Classification of Cases

\begin{tabular}{lccccc}
\hline & & \multicolumn{3}{c}{ Predicted Group Membership } \\
\cline { 3 - 6 } & Total & & $\begin{array}{c}\text { Not Enrolled for Two } \\
\text { Years }\end{array}$ & \multicolumn{2}{c}{$\begin{array}{c}\text { Retained for two } \\
\text { Years. }\end{array}$} \\
Groups & $N$ & $N$ & $\%$ & $N$ & $\%$ \\
\hline Not Enrolled for Two Years & 14374 & 10034 & 69.8 & 4340 & 30.2 \\
Retained for Two Years. & 6019 & 1817 & 30.2 & 4202 & 69.8 \\
\hline
\end{tabular}




\author{
CHAPTER V \\ Summary, Conclusions, and Recommendations
}

\title{
Summary
}

The purpose of the study was to determine retention rates among youth enrolled in West Virginia’s 4-H youth programs and to identify characteristics or trends associated with 4-H member retention. The study explored various factors associated with retention of 4-H members.

The objectives of the study were:

1. Identify characteristics of youth who were retained as 4-H members.

2. Identify characteristics of youth who failed to remain active in 4-H.

3. Examine trends within characteristics associated with retention of 4-H members.

4. Examine trends within characteristics associated with individuals who failed to remain active in $4-\mathrm{H}$.

5. Evaluate project subject areas to determine if an association exists between various subject areas and the retention or failure to retain $4-\mathrm{H}$ members.

The enrollment in 2002 was 20,463 4-H members. For two-year cycle 2002 to 2004 only 30\% of those member. Of the members retained for the two year period between 2002 and 2004, about 40\% of the members were male and 60\% were females. This differs slightly from the 2002, 2003 and 2004 yearly retention data where there was a slight increase in the number of females retained and a slight decrease in the number of males that were retained. The mean grade of 4-H members enrolled in 2002, 2003, and 2004 increased slightly each of these years, to a mean grade of 6.08 in 2004 . The members that were retained for the two year cycle were found to have a slightly lower 
mean grade of 6.01. Those individuals that were not retained from 2002 to 2003 and 2003 to 2004 have a lower mean grade.

Members that were retained from 2002 to 2004 had a mean age of 12.05. The mean age of those individuals who reenrolled in 2002, 2003, and 2004 increased slightly each in the years with a mean of 12.22 in 2004. Those individuals that were not retained between 2002 to 2003 and 2003 to 2004 had a slightly lower mean age than those individuals retained over the two-year cycle.

The number of years of membership for those individuals enrolled in 2002, 2003, and 2004, decreased slightly to a low of 2.99 in 2004. The individuals that were retained from 2002 to 2004 had an average of 3.56 years membership. Those individuals that were not retained between 2002 and 2003 had a mean one year less than that of those members that were retained during the same time. This was consistent with these individuals enrolled between 2003 and 2004.

In 2002, 2003, and 2004, the highest enrollment numbers were for those individuals that enrolled for their first year. Of those members that were retained from 2002 to 2003 and from 2003 to 2004, the largest enrollment group in each of these years was first year members. There was no difference in the enrollment number of those retained and those not retained during the same time period.

Of the projects taken by individuals during 2002, 2003, and 2004 the project category that had the most members attempting at least one project was in each of these years was the "miscellaneous" project category. This could be due to a large number of members that take the "This Is 4-H" project designed as an introduction to 4-H. Of those individuals retained from 2002 to 2004, the project category that had the most members 
attempting at least one was from the "animal science” project category. More females attempted at least one of the "animal science" projects then males. Of those individuals retained between 2002 to 2003 and 2003 to 2004, the “animal science” projects had the most members attempted at least one project. For those that were not retained during the same time, the "miscellaneous" category had the most members who attempted at least one project.

Discriminate analysis was conducted between individuals that were retained between 2002 and 2004 and those individuals that were not retained. The discriminate function could account for $20 \%$ of the variants that could be explained by each of the two groups. The classification of cases correctly classified 70\% cases.

\section{Conclusions}

The following conclusions were drawn based on the results of the study:

- The gender ratio of males $44 \%$ and females 56\% is unchanged during 2002, 2003, and 2004. The program has more females participate even though the number of club members participating declined each of these three years.

- The mean age and grade level has increased during 2002, 2003, and 2004. This could indicate that not as many younger members are joining or the members are joining at a slightly older age and higher grade level.

- During 2002, 2003, and 2004, the “miscellaneous” project category had the largest number of projects attempted. The first year members made up the largest membership groups and are often encouraged to take the "This is 4-H Project" during their first year in the program. 
- The members retained between 2002 and 2003 were found to have retention ratios, gender ratios, mean age, mean grade level, and mean years of membership only slightly different from those individuals retained between 2003 and 2004.

- The individuals that were retained between 2002 and 2004 had a mean age of 12.05 which is slightly less than mean age of individuals that were retained a single year cycle. This indicates the 4-H program retains more younger members.

- Members that were retained for the two years cycle will be part of the program slightly longer than those that were not retained. The years of membership that were retained for a two year cycle between 2002 and 2004 have a slightly larger mean.

- Those individuals attempting at least one project from the “animal science” project category are more likely to be retained. Those individuals who drop out were more like attempt at least one from project the "miscellaneous" category.

\section{Recommendations}

Based on these results the following recommendations are made by the researcher:

1. Continued study is needed that will incorporate more years of 4-H enrollment data. This would allow the tracking of individuals retained for longer periods of time to determine trends in 4-H enrollment and retention.

2. Study could be conducted with enrollment data used and combined with activities individuals participated in during the year. This should include the variable of the individual taking part in a resident camping experience. Membership trends would be examined using these variables.

3. Additional studies could focus on retention and project categories and include information related to parental involvement and member satisfaction levels with their 
experiences. Projects like Animal Science often have some component of parent involvement which might affect member retention.

4. Continued study of the 4-H enrollment data that would include the obtaining and recording of project completion information indicating those 4- $\mathrm{H}$ members that attempted and completed 4-H projects within a given year could provide insight into retention. 


\section{REFERENCES}

Ary, D., Jacobs, L. C., Razavieh, A. (1972). Introduction to research in education. New York: Holt, Rinehart and Winston.

Astroth, K. (1985). The challenge of retaining 4-H members [Electronic version]. Journal of Extension, 23(3). Retrieved June 30, 2005 from http://www.joe.org/joe/1985fall/sa4.html

Byerley, M. (1972). Factors which influence the four-H membership status of ninth and tenth grade girls in Bradley County, Tennessee: A Research Summary. (ERIC No. ED076866).

Discriminant Analysis Function. (n.d.) Retrieved June 30, 2005, from http://www2.chass.ncsu.edu/garson/PA765/discrim.htm\#constant

Gottlieb, D., Lewis, D., Heinsohn, A. (1974). Study of the 4-H youth and 4-H programming. The Pennsylvania State University. (ERIC Document Reproduction Service No. ED094248).

Hartley, R. S. (1982). Factors and characteristics associated with reenrollment and dropout of younger first year 4-H members in selected West Virginia counties (Doctoral dissertation, West Virginia University, 1982).

Heinsohn, A. L. \& Lewis, R. B. (1997). Why do teens drop out?: A developmental view [Electronic version]. Journal of Extension 33(1). Retrieved June 16, 2005 from http://www.joe.org/joe/1995february/comm1.html

Hair, J. F., Anderson, R. E., Tatham, R. L., \& Black, W. C. (1995). Multivariate data analysis (4 $4^{\text {th }}$ ed.). Englewood Cliffs, NJ: Prentice Hall. 
Ladewig, H., Thomas, J. (1987). Does 4-H make a difference? College Station, TX:

Texas A and M University, Texas Agricultural Experiment Station. (ERIC Document Reproduction Service No. ED282682).

Lindsay, C. (1972). The 4-H project leader. (Y733) [Brochure]. University of MissouriColumbia.

West Virginia University Extension Service. (1986). Meet 4-H There's something in it for you! (1986). (4-H-L-613-79). Author.

National 4-H Headquarters. (n.d.). 2000 programs of excellence. Retrieved September 28, 2003, from http://national4-hheadquarters.gov/excellence/2000/facts.htm

National 4-H Headquarters. (n.d.). 4-H history timeline. Retrieved September 28, 2003, from http://national4-hheadquarters.gov/4h_timeline.htm

Norland, E., \& Bennett, M. (1993). Youth participation [Electronic version]. Journal of Extension, 31(1). Retrieved June 6, 2005 from http://www.joe.org/joe/1993spring/a5.html.

Patten, M. L. (2002). Understanding research methods ( $3^{\text {rd }}$ ed.). Los Angeles, CA: Pyrczak Publishing.

Ritchie, R. M. \& Resler, K. M. (1993). Why Youth Drop Out of 4-H. [Electronic version]. Journal of Extension 31(1). Retrieved June 6, 2005 from http://www.joe.org/joe/1993spring/rb3.html

Wingenbach, G. S., Nestor, C., Lawrence, L. D., Gartin, S. A., Woloshuk, J., \& Mulkeen, P. (2000). Marketing Strategies for Recruiting 4-H Members in West Virginia [Electronic Version]. Journal of Agricultural Education, 41(1), 88-94. Retrieved June 6, 2005 From HTTP://Pubs.Aged.Tamu.Edu/Jae/Pdf/Vol41/41-01-88.Pdf. 
Wingenbach, G. S., Meighan, T., Lawrence, L. D., Gartin, S. A., Woloshuk, J., (1999). Associated factors in recruitment and retention of 4-H members in West Virginia [Electronic version]. Journal of Agricultural Education, 40, 23-29. Retrieved June 6, 2005 from http://pubs.aged.tamu.edu/jae/pdf/vol40/40-01-23.pdf 


\section{APPENDIX}

\section{4-H Member Enrollment Card}

Buxtension Service

West VirginiaUntventy.

4-H-M-951-03

\section{4-H Member \\ Enrollment Card}

Year Beginning October 1, 2003

Name of Club

Name

Address

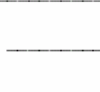

last fint

first

street, nute, bax

phone number

Birth Date

middle initial

nickname

zip

Residence (Check One)

residence

Towns under 10,000 (Rural Non-Farm)

J Towns and Cities 10,000-50,000

- Central Cities over 50,000

Etheicity and Racial Dat

$\checkmark$ Hispanic or Latino $\square$ Not-Hispanic or Latino Nationality Code (Leader Use Only)

\section{Club ID}

AA Club Type

This is my —year in 4-H. Grade in School

Name of School

\section{4-H Projects: Put an (x) in the box for the project(s) you plan to carry this year.}

ANIMAL SCIENCE

(For beef, dairy, borse, sheep, swine, poultry, dog, rabbit, goat, pets, and cat projects, you must also select an animal record guide.)

10310 Uet Science I - The Normal Animal

10320 Vet Science II - Animal Disease

1041 Bite Into Beef (Beef 1) Year

$1042_{\text {_ }}$ - Here's the Beef (Beef 2) Year

1043 _ Leading the Charge (Beef 3) Year

10440 4-H Beef Heifer Record Guide

10450 4-H Feeder Calf Record Guide

10460 4-H Market Steer Record Guide

1051_ 口 Dig Into Dairy (Dairy 1) Year

1052_ Mocoving Ahead (Dairy 2) Year

1053 _ Leading the Way (Dairy 3) Year -

10540 4-H Dairy Record Guide

(List number of animal records needed.)

$\overline{1061}$ \ Horsing Around (Horse 1) Year
1062_ $\square$ Galloping Ahead (Horse 2) Year

1063_ B Blazing Trails (Horse 3) Year _-

10640 - 4-H Horse Record Guide

1071_ Lambs, Rams, and You (Sheep 1) Year

1072 - Shear Delight (Sheep 2) Year

1073 _ Leading the Flock (Sheep 3) Year

10740 4-H Breeding Sheep Record Guide

10750 4-H Market lamb Record Guide

1081_ Growing with Swine (Swine 1) Year

1082 - Becoming Swine Smart (Swine 2) Year

1083_ Entering the Arena (Swine 3) Year

1084_ 4-H Swine Record Guide (Market/Purebred)

1101_ Scratching the Surface (Poultry 1) Year

1102 _ Testing Your Wings (Poultry 2) Year -

1103 _ Flocking Together (Poultry 3) Year

11040 4-H Poultry Record Guide

1111_ $\square$ Wiggles 'n Wags (Dog 1) Year

1112 _ Canine Connection (Dog 2) Year

1113 Leading the Pack (Dog 3) Year
11140 4 4-H Dog Record Guide

1121_ What's Hoppening? (Rabbit 1) Year

1122_ Making Tracks (Rabbit 2) Year

1123_ a All Ears (Rabbit 3) Year

11240 4-H Market Rabbit Record Guide

1131_ $\square$ Getting Your Goat (Dairy Goat 1) Year

$1132_{2}$ - Stepping Out (Dairy Goat 2) Year

1133 _ Showing the Way (Dairy Goat 3) Year

1134_ 4-H Goat Record Guide (Dairy/Meat)

1135 _ Just Browsing (Meat Goat 1) Year _-

1141_ $\square$ Pet Pals (Pets 1) Year

1142 U Scurrying Ahead (Pets 2) Year

1143 _ Scaling the Heights (Pets 3) Year

11440 4-H Pets Record Guide

(List kind of pet

1151 _ Purr-fect Pals (Cat 1) Year _-

$1152_{-}$口 Climbing Up! (Cat 2) Year -

11540 \4-H Cat Record Guide

11990 a Self-Determined Animal Science
PIANT SCIENCE AND CROPS

13220 Potatoes

13320 Strawberry Planting

13330 U Stra wberry Harvesting

13420 Flower Arranging

13510 Meet the Plants

13520 Indoor Gardening

13530 U Vegetable Gardening

13540 Jandscape Gaden

13990 Self-Determined Plant Science and Crops MECHANICAL SCIENCE

$15210 \square$ Unit I Tractor

15220 U Unit II Tracto

1541_ Crank It Up (Small Engines 1) Year

1542_ U Warm It Up (Small Engines 2) Year

1543_ 口 Tune It Up (Small Engines 3) Year

1562_ $\square$ Bicycle Adventures (Level 2) Year

1563 - Bicycle Adventures (Level 3) Year

1571_ Magic of Electricity (Electricity 1) Year

1572 - Investigating Flectricity (Flectricity 2) Year

1573 - Wired for Power (Flectricity 3) Year

1574 Entering Flectronics (Electricity 4) Year

15910 Entering Elec

1601 1

1601 - Measuring Le (Woodworking 1) Year

1602 - Making the Cut (Woodworking 2) Year

1603 _ Nailing It Together (Woodworking 3) Year

1604 _ I Finishing Up (Woodworking 4) Year

NATURAL RESOURCES AND ENVIRONMENT

1711_ $\square$ Spring Wildflowers - Year

$1712_{2} \square$ Summer and Fall Wildflowers - Year _-

1731_ $\square$ Creepy Crawlies (Entomology 1) Year _-

1761_ $\square$ Tree Identification - Year _-

17720 Grapping

1773 G Birds - Year

1781_ $\square$ Take the Bait (Sportfishing1) Year ___

1782_ Reel in the Fun (Sportfishing 2) Year 1783 Cast into the Future (Sportfishing 3) Year $23010 \square$ Reduce, Reuse, Recycle

19990 Self-Determined Natural Resources and Environment

LEADERSHIP AND COMMUNITY INVOLVEMENI 21410 प Teens Take the Lead (Year 1)

21420 a Teens Take the Lead (Year 2)

21430 Geens Take the Lead (Year 3)

21990 Self-Determined Leadership and Community Involvement

LEISURE AND CULTURAL EDUCATION

2247 - 22510 Recreation - Year
Gxploring 4-H, Your Family, the World, or Arts

22990 Self-Determined Leisure and Cultural Education

HEALTH AND SAFETY

2411_ D Discovering Myself (Health A) Year __

2412 _ Fun with Friends (Health B) Year

2413_ 口 Teen Talk (Health C) Year

2414_ $\square$ Preparing for the Future (Health D) Year

24990 Self-Determined Health and Safety

INDIVIDUAL AND FAMILY RESOURCES

$$
\text { Child Care }
$$

30010 u Living and Learning with Childre

30020 More Living and Learning with Children

30030 Teens Learn About Children

Management

30120 Dollar Sense

30130 Making Your Dollars Make SenSe

30140 a Money-Go-Round

3015_ Money Fundamentals (Financial Champions 1)

$$
\text { Year }
$$

3016 Money Moves (Financial Champions 2) Year 45200 4-H learn to Earn
Clothing

30410 Getting in Step with Yourself-Clothing I

30420 Growing in Personal Skills-Clothing I

30430 Developing Your Unique Self-Clothing III

30430 Developing Your Lnique Self-Cloth

30440 Becoming an Individual-Clothing IV Clothing $\mathrm{V}$

\section{Food Preparation}

3061 _ U Six Easy Bites (Level A) Year _-

3062_ $\square$ Tasty Tidbits (Level B) Year _

3063_ Y You're the Chef (Level C) Year

3064_ $\square$ Foodworks (Level D) Year _-_

Personal Development

3110 _ 4-H Charting-A Journey Begun... Year

32990 Gelf-Determined Individual and Family Resource

COMMUNICATIONS ARTS AND SCIENCES

40311 \ Photography I-A

40312 ] Photography I-B

40320 Photography II

$40330 \square$ Adventures With an Adjustable Camer

40410 4-H News Reporter

4051_ $\square$ Booting Up (Computers 1) Year -

4052 Adding On (Computers 2) Year

4053_ Reaching Beyond (Computers 3) Year

40990 U Self-Determined Communications Arts

$$
\text { and Sciences }
$$

MISCELLANEOUS

32100 4-H Nutrition Group - FNP

This Is $4-\mathrm{H}$

45110 a Self-Determined Miscellaneous

www.wou.edu/ exten/infores/pubs/4hpubs.btm 